\title{
Diagnosing GORD in respiratory medicine
}

\author{
Chris J. Timms ${ }^{1}$, Deborah H. Yates ${ }^{2}$ and Paul S. Thomas ${ }^{1,3 *}$ \\ 1 Faculty of Medicine, University of New South Wales, Sydney, NSW, Australia \\ ${ }^{2}$ Thoracic Medicine Department, St. Vincent's Hospital, Sydney, NSW, Australia \\ ${ }^{3}$ Respiratory Medicine Department, Prince of Wales Hospital, Sydney, NSW, Australia
}

Edited by:

Mario Malerba, University - Hospital,

Italy

Reviewed by:

Paolo Montuschi, Università Cattolica

del Sacro Cuore, Italy

Nadia Mores, Catholic University

School of Medicine, Italy

Alessandro Radaeli, Spedali Civili, Italy

*Correspondence:

Paul S. Thomas, Department of

Respiratory Medicine, Prince of

Wales Hospital, Sydney, NSW 2031,

Australia.

e-mail:paul.thomas@unsw.edu.au
Gastroesophageal reflux disease (GORD) is increasing in prevalence and is highly associated with several lung diseases such as asthma and COPD. Current diagnostic methods are imperfect, being insensitive, non-specific, expensive, or invasive. An accurate diagnosis of GORD can aid effective treatment and have significant clinical impact. Novel methods such as exhaled breath condensate analysis and electronic nose technology have the potential to improve the accuracy of diagnosing GORD.

Keywords: gastroesophageal reflux disease, pepsin, asthma, COPD, exhaled breath condensate, electronic nose

\section{INTRODUCTION}

Gastroesophageal reflux is the passage of gastric contents through the gastric cardia into the esophagus. The Montreal consensus of 2006 defined gastroesophageal reflux disease (GORD) as a pathology which "develops when the reflux of stomach contents causes troublesome symptoms or complications" (Vakil et al., 2006). The ambiguity of this definition hints at the imprecise nature of GORD diagnosis. Clinically, the diagnosis of GORD is most commonly achieved using symptom evaluation with a validated questionnaire, empiric proton pump inhibitor (PPI) therapy, or esophageal $\mathrm{pH}$ monitoring. Research is ongoing into these and other methods of diagnosis, as well as risk factors and associations, in order to develop more effective clinical management.

Risk factors for developing GORD include hiatus hernia (Beaumont et al., 2010), obesity (Sise and Friedenberg, 2008; Fisichella and Patti, 2009), pregnancy (Baron and Richter, 1992), and smoking (Isolauri and Laippala, 1995). GORD is also associated with many factors, including the lung diseases COPD and asthma (Amarasiri et al., 2010). COPD is characterized by a minimally reversible reduction in expiratory airflow whilst asthma is a common disease that is characterized by airflow obstruction that changes both with treatment and spontaneously. Whether the association of COPD and asthma with GORD represents cause or effect has yet to be established (Maher and Darwish, 2010). It has been shown, however, that treatment of GORD can improve symptoms if not lung function in asthmatics (Gibson et al., 2000). In COPD patients, the presence of GORD is associated with increased exacerbations of COPD (Rascon-Aguilar et al., 2006; Terada et al., 2008) and limited evidence suggests treatment with PPIs can improve symptoms if not lung function (Eryuksel et al., 2009).

The estimates of the prevalence of GORD in COPD patients range widely in the literature. The limited number of studies which used the gold standard of $24 \mathrm{~h}$ esophageal $\mathrm{pH}$ monitoring estimated the prevalence between 19 (Dent et al., 2005) and $57 \%$ (Kempainen et al., 2007). The disparities in prevalence may be attributable to the demographics of the study population (e.g., one study which had an almost entirely male cohort; Casanova et al., 2004), different monitoring devices, use of proximal or distal monitoring, and variability in the $\mathrm{pH}$ criteria (Delaney, 2004).

The prevalence of GORD in asthma has varied between studies using $\mathrm{pH}$ monitoring from 36 to 55\% (Kiljander and Laitinen, 2004; Leggett et al., 2005). Several studies have shown an increase in the prevalence of GORD in both difficult-to-control asthma and more severe asthma (Leggett et al., 2005). Disparities in prevalence studies again may be attributable to study demographics, monitoring techniques, and $\mathrm{pH}$ criteria.

Gastroesophageal reflux disease is a concern in COPD, asthma, and many other lung diseases as it may cause bronchospasm and related wheezing or coughing (Canning and Mazzone, 2003; Rascon-Aguilar et al., 2006). A recent Cochrane review examined the conflicting evidence on the benefit of GORD treatment [proton pump inhibitors (PPIs), histamine antagonists, and surgical treatment] for managing asthmatic lung disease. PPI treatment, histamine antagonist therapy or surgical therapy may improve asthma-related quality of life and decrease symptoms in some groups of patients; however such treatment may not improve lung function (Gibson et al., 2000). Furthermore, it is difficult to predict which types of patients will benefit from this. Being able to diagnose GORD is an important aid to management of a patient's lung disease even if it only improves symptoms rather than lung function.

Current methods for diagnosis of GORD have limited accuracy or are invasive. The most commonly used methods of diagnosis are a symptom questionnaire or empiric PPI therapy. These methods however have limited sensitivity and specificity. Esophageal $\mathrm{pH}$ monitoring $(24 \mathrm{~h})$ with multichannel intraluminal impedance 
(MII) monitoring is the gold standard, but is invasive and time consuming (Aanen et al., 2008).

\section{CURRENT METHODS OF GORD DIAGNOSIS SYMPTOM OUESTIONNAIRES}

Gastroesophageal reflux disease is often suspected because of symptoms reported by the patient and these symptoms can be formally assessed using validated questionnaires. Questionnaires are quick, non-invasive, and inexpensive but cannot detect asymptomatic GORD.

Several questionnaires have been developed and validated. These include the Reflux Disease Questionnaire (RDQ; Dent et al., 2010), the frequency scale for symptoms of gastroesophageal (FSSG) Reflux Disease (Kusano et al., 2004), and the Re-Quest Questionnaire (Rubin et al., 2008). Symptom evaluation is also useful for assessing treatment efficacy. A study of night-time GORD symptoms in otherwise healthy participants indicated that night-time symptoms were both common, occurring in $45 \%$ of patients, and indicated a greater severity of disease burden than patients with primarily or exclusively day time symptoms (Dean. et al., 2010).

\section{LARYNGOPHARYNGEAL EXAMINATION}

Following a thorough clinical history and symptom assessment, the laryngopharynx may be examined for signs of reflux. Examination of the laryngopharynx provides valuable diagnostic information to symptoms and can give an indication of impact on the patient. Laryngopharyngeal reflux differs from GORD as it may also present with throat symptoms such as dysphonia, pseudodysphagia, and globus (Pearson et al., 2011).

Examination of the laryngopharynx is performed using a flexible or rigid laryngoscope. Typical findings from a laryngopharyngoscopy of a patient with laryngopharyngeal reflux include: erythema, posterior commissure hypertrophy, granulomas, vocal cord dysfunction, pseudosulcus, edema, ventricular obliteration, erythematous mucosa in the nasopharynx, and red mucosa in the lingual tonsils. Findings on laryngopharyngoscopy consistent with reflux disease are often followed by an empiric trial of PPIs (Pearson et al., 2011).

\section{EMPIRIC PROTON PUMP INHIBITOR TRIAL}

A common step after presentation with GORD symptoms is to trial an empiric course of PPIs before performing further investigations. A PPI therapeutic trial has been shown to be fairly sensitive (68-92\%) with a wide range of specificity (36-100\%) in diagnosing GORD-related non-cardiac chest pain (Fass et al., 1998; Bate et al., 1999; Pandak et al., 2002; Cho et al., 2010). In addition, empirical treatment with PPIs ensures early therapeutic intervention. One recent study has however cast some doubt on whether symptom response to $40 \mathrm{mg}$ of esomeprazole over a 2 -week period is sensitive or specific for the diagnosis of GORD when compared to esophageal pH monitoring (Dent et al., 2010). Empirical PPI therapy however remains the main treatment for GORD.

\section{ESOPHAGEAL PH MONITORING}

Whilst symptomatic evaluation and empiric PPI trials are the most commonly used methods of diagnosis, esophageal $\mathrm{pH}$ monitoring is highly sensitive, and specific. Esophageal pH monitoring involves leaving a $\mathrm{pH}$ probe $5 \mathrm{~cm}$ superior to the lower esophageal sphincter for a 24 -h period. During the $24-\mathrm{h}$, the patient records their meals, symptoms, and sleep. The esophageal acid exposure is then determined by the percentage of the 24-h period that the $\mathrm{pH}$ is $<4.0$. Symptoms do not always correlate with $\mathrm{pH}<4$, however, as symptoms can result from non-acidic as well as acidic reflux.

Esophageal $\mathrm{pH}$ monitoring can be supplemented by MII testing to detect non-acidic reflux. MII testing identifies causes of reflux symptoms which occur without lowering the $\mathrm{pH}$ below 4 . Other causes of reflux symptoms include minor acid ( $\mathrm{pH} 4-7)$, nonacid, and gas reflux. Esophageal $\mathrm{pH}$ monitoring with MII testing is sensitive and specific however it is invasive, expensive, and time consuming.

In the detection of acid reflux, $24 \mathrm{~h} \mathrm{pH}$ monitoring without MII yields a sensitivity of $68 \%$, and a specificity of $67 \%$ (Amine et al., 2007). For the detection of weakly acidic reflux compared with MII, pH alone had a sensitivity of only $28 \%$. The use of $24 \mathrm{~h} \mathrm{pH}$ monitoring alone for the detection of acid reflux is very sensitive but lacks specificity compared with MII-pH monitoring (Amine et al., 2007).

\section{ENDOSCOPY}

Endoscopy is also invasive and has high sensitivity for diagnosing mucosal injury but is not typically performed as an initial investigation for GORD symptoms. Endoscopy is performed in a minority of patients to obtain further information relating to GORD and is useful for detection of esophagitis, erosions, strictures, ulcers, neoplasia, and Barrett's esophagus (Reid et al., 1988).

Whilst invasive tests such as endoscopy and esophageal $\mathrm{pH}$ monitoring are effective as diagnostic tools, there is no current test with high sensitivity and specificity which is also inexpensive and non-invasive. A potential method for screening and diagnosing GORD and micro-aspiration in patients may be the profiling of patients' breath.

\section{NOVEL METHODS OF DIAGNOSING GORD}

Breath profiling is used informally by doctors in a range of clinical scenarios, from detecting the "fruity breath" of diabetic patients in ketoacidotic states to smelling alcohol on the breath. The breath can be formally profiled using a range of tools including electronic nose analysis, fractional nitric oxide measurements, and exhaled breath condensate $(\mathrm{EBC})$ collection. With regard to reflux, one method may be the detection of either pepsin or bile acids in the exhaled breath secondary to aspiration of gastric contents. Nitric oxide levels and volatile organic compounds are also of significant interest and are examined using fractional exhaled nitric oxide measurements and electronic nose technology.

\section{PEPSIN - A DIAGNOSTIC MARKER OF REFLUX}

Pepsin is a gastric enzyme that degrades food proteins into peptides. In patients with GORD, elevated levels of pepsin have recently been described in the respiratory epithelial lining fluid using EBC (Krishnan et al., 2007), using bronchoalveolar lavage (BAL; Farrell et al., 2006), and via the sampling of middle ear effusions of children with pharyngeal reflux (Abd El-Fattah et al., 
Table 1 | Pepsin concentration in EBC and BAL.

\begin{tabular}{|c|c|c|c|}
\hline Study population & $\begin{array}{l}\text { Sampling } \\
\text { method }\end{array}$ & Pepsin concentration & Analytical techniques \\
\hline $\begin{array}{l}\text { Adult lung transplant (LTx) patients } \\
\text { experiencing GORD (Krishnan et al., } \\
\text { 2007) }\end{array}$ & $\mathrm{EBC}$ & $\begin{array}{l}\text { Higher in the LTx with GORD (mean } \\
\text { concentration } 4.31 \mathrm{ng} / \mathrm{mL} \text { ) than controls } \\
\text { (mean concentration } 0.08 \mathrm{ng} / \mathrm{ml} \text { ) }\end{array}$ & $\begin{array}{l}\text { In-house ELISA assay using antiporcine pepsin } \\
\text { antibodies (Krishnan et al., 2002) } \\
\text { Mean concentration compared using a } \\
\text { Mann-Whitney } U \text { test (Krishnan et al., 2002) }\end{array}$ \\
\hline $\begin{array}{l}\text { Cystic fibrosis patients (McNally } \\
\text { et al., 2011) }\end{array}$ & $\mathrm{BAL}$ & $\begin{array}{l}\text { Higher in the CF group (mean concentration } \\
24.4 \mathrm{ng} / \mathrm{ml}) \text { than in controls }(4.3 \mathrm{ng} / \mathrm{ml})\end{array}$ & $\begin{array}{l}\text { Pepsin was measured by an in-house ELISA assay } \\
\text { with antiporcine pepsin antibodies (Farrell et al., 2006) } \\
\text { Groups and subgroups were analyzed using } \\
\text { two-tailed independent sample students' } t \text { tests } \\
\text { when normally distributed or by the non-parametric } \\
\text { Mann-Whitney } U \text { test, as appropriate }\end{array}$ \\
\hline $\begin{array}{l}\text { Children with GORD (Farrell et al., } \\
\text { 2006) }\end{array}$ & $\mathrm{BAL}$ & $\begin{array}{l}\text { Pepsin concentration ranged from } 0 \text { to } \\
100 \mathrm{ng} / \mathrm{ml}\end{array}$ & $\begin{array}{l}\text { Pepsin was measured using an in-house ELISA assay } \\
\text { with antiporcine pepsin antibodies (Farrell et al., 2006) } \\
\text { Correlations between factors were tested using the } \\
\text { two-tailed Spearman correlation coefficient }\end{array}$ \\
\hline $\begin{array}{l}\text { Lung allograft patients Ward et al., } \\
\text { 2005) }\end{array}$ & $\mathrm{BAL}$ & $\begin{array}{l}\text { Median concentration of } 109 \mathrm{ng} / \mathrm{ml} \text { (range } \\
35-1375 \text { ) in lung allograft patients }\end{array}$ & $\begin{array}{l}\text { A locally developed ELISA was performed to measure } \\
\text { pepsin. The assay was based on a monospecific } \\
\text { antibody to porcine pepsin with a lower limit of } \\
\text { detection of }<1 \mathrm{ng} / \mathrm{ml} \\
\text { Two-tailed Mann-Whitney } U \text { tests were performed to } \\
\text { compare the median pepsin concentration between } \\
\text { groups }\end{array}$ \\
\hline $\begin{array}{l}\text { Children with different chronic lung } \\
\text { diseases (Starosta et al., 2007) }\end{array}$ & $\mathrm{BAL}$ & $\begin{array}{l}\text { Mean pepsin concentration varied from } 0 \text { to } \\
1517 \mathrm{ng} / \mathrm{ml} \text { across a spectrum of GORD }\end{array}$ & $\begin{array}{l}\text { A modification of the proteolytic enzyme assay } \\
\text { method was used to measure pepsin } \\
\text { The non-parametric Mann-Whitney } U \text { test was used } \\
\text { to compare between groups }\end{array}$ \\
\hline
\end{tabular}

2007; see Table 1). The advantage of analyzing pepsin is that it is not normally found in the lung and therefore should be specific for reflux.

\section{BRONCHOALVEOLAR LAVAGE}

Bronchoalveolar lavage is an invasive but direct method of sampling the lung epithelial lining fluid. BAL involves inserting a bronchoscope through the mouth or nose into the lungs. The bronchoscopist can instill fluid into a small part of the lung and then collects the fluid for examination.

Pepsin has been detected in the BAL of subjects in several lung diseases. Some lung allograft patients (Ward et al., 2005) have been shown to have pepsin present in BAL, as have children with different chronic lung diseases including chronic bronchitis without a determinable cause; allergic asthma; recurrent pneumonia; bronchiectasis; tracheomalacia; primary ciliary dyskinesia; and bronchiolitis obliterans (Starosta et al., 2007).

\section{EXHALED BREATH CONDENSATE}

Exhaled breath condensate is the breath water vapor that has been condensed, typically via cooling using a collection device (commonly to $4^{\circ} \mathrm{C}$ or sub-zero temperatures). EBC reflects changes in the respiratory fluid that lines the airways and is an inexpensive, non-invasive sampling tool. Pepsin has been demonstrated in the EBC of patients who were clinically suspected to have reflux associated cough (Strugala et al., 2009).

Exhaled breath condensate has been used to investigate the relationship between reflux symptoms and lung disease in one previous paper (Terada et al., 2008). EBC pH was studied in 82 patients with COPD and 42 controls and was found to be significantly lower in patients with GORD (Terada et al., 2008).GORD symptoms were significantly predictive of COPD exacerbation and an inverse correlation was determined between $\mathrm{EBC} \mathrm{pH}$ and the FSSG score (Terada et al., 2008).

Exhaled breath condensate $\mathrm{pH}$ decreases in active inflammatory lung conditions, including asthma and particularly during exacerbations (Brunetti et al., 2004) but not in COPD (Antus et al., 2010). Aspiration of acidic stomach contents may however influence the $\mathrm{pH}$ of EBC and its accuracy as a marker of disease. Pepsin therefore has potential use as a marker of gastric aspiration if an acidic EBC is detected (Hunt et al., 2000). Pepsin levels have also been shown to correlate with percentages of neutrophils, levels of protein carbonyls, and levels of IL-8 in BAL (Starosta et al., 2007).

\section{ELECTRONIC NOSE TECHNOLOGY}

An electronic nose is a device that partially imitates the mammalian olfactory system which can formally analyze breath profiles. Several different types are now commercially available. 
Usually, it utilizes sensor array and pattern recognition algorithms to identify components in vapor. An array of sensors using coated electrodes or polymer composites respond to the volatile components, causing the coating to change or polymer to expand like a sponge, changing the electrical resistance of the composites. The change in resistance is measured and used to indicate the presence of a pre-trained pattern. Another type of electronic nose makes uses of an array of quartz microbalance gas sensors coated by molecular films of metalloporphyrins. The array of sensors quantifies the amount of molecules that are absorbed by the molecular films by the changes in resonant frequency. These changes in frequency are then analyzed by pattern recognition algorithms (Montuschi et al., 2010).

The precise chemicals detected are not identified, only a pattern or "smell print" is established for each condition. There are currently several electronic noses in use, e.g., the Cyranose 320 (Smith's Detection, San Diego, USA), the Bloodhound (Scensive Technologies, Normanton, UK), and the Graffit-e-Nos (E-Nose Pty Ltd, Sydney, Australia).

Whilst initially developed for use in situations such as indoor atmosphere maintenance, military gas analysis, and food preparation, electronic nose technology has found applications in medicine. The electronic nose has the potential to sample volatile compounds in breath, wounds, and bodily fluid. Due to the diverse range of samples which electronic nose technology can assess, research is ongoing in diverse disorders such as urinary tract infections (Pavlou et al., 2002), lung cancer (Machado et al., 2005; Tran et al., 2010), cerebrospinal fluid leak (Thaler et al., 2000), and diabetes mellitus (Ping et al., 1997) among others.

Standardization of breath sampling is critical for the continued use of electronic nose technology. Use of a streamlined, validated, protocol is crucial for comparison between studies. One development in exhaled breath sampling was the use of a two Tedlar bag valve system which allows sampling of the lower respiratory tract only (D'Amico et al., 2010). A significant problem with breath sampling is potential contamination by food, drinks, and other items in the upper airways. Sampling of only the lower respiratory tract helps to eliminate some of the variability associated with the upper airways and in general, alveolar air is contained in the last portion of an expiratory breath. Montuschi et al. (2010) also demonstrated sampling of alveolar air by an electronic nose to be accurate in detecting atopic asthma, particularly in conjunction with exhaled nitric oxide testing (Montuschi et al., 2010).

\section{Current diagnostic potential in GORD}

Whilst no study has examined whether the electronic nose can separate reflux patients from healthy controls, several studies have assessed the ability of the electronic nose to discriminate the breath profiles of patients with asthma, COPD, lung cancer, and other lung diseases. With pre-existing information on lung disease breath profiles, it is possible not only to study GORD in isolation but also in conjunction with lung disease.

Breath profiling has been performed on several lung diseases. At a basic level, changes in breath profiles resulting from active smoking allow for discrimination between smokers and nonsmokers with a sensitivity of 95\% (Chen et al., 2009). Smokers overlap with COPD patients, however patients with COPD had a negligible change in breath compared to asthma, ex-smokers, and non-smokers (Fens et al., 2009). One study in the bronchoscopy unit of a large hospital showed the electronic nose was able to discriminate between lung cancer and healthy controls. This study also showed a modification of breath by other diseases including pleurisy, bronchitis, and COPD (D'Amico et al., 2010).

A key point that has emerged from the study of several lung diseases is that the electronic nose is most effective when distinguishing between two distinct subgroups. When Fens et al. (2009) analyzed asthma, COPD, smokers, and non-smokers all together the sensitivity was only $56 \%$, although this was statistically significant. Electronic noses may be best used distinguishing between two clearly defined groups.

\section{GAS CHROMATOGRAPHY AND MASS SPECTROMETRY}

Gas chromatography and mass spectrometry involves a combination of gas liquid chromatography and mass spectrometry to identify various substances. It is particularly useful for identifying traces of compounds that are detectable only at very low levels.

Gas chromatography mass spectrometry has been used in analysis of breath in parallel with the electronic nose in asthma and normal subjects (Hyspler et al., 2000; Dallinga et al., 2010). To date no analysis of a patient's breath with GORD has been performed using GCMS. The use of GCMS is limited in standard clinical practice due to its size, cost, and technical requirements. The electronic nose however has the potential to allow real time measurement of exhaled breath in clinical practice, but this requires appropriate evaluation.

Novel, non-invasive but accurate methods of confirming a diagnosis of GORD could help the significant numbers of patients needlessly on PPI treatment and also those patients who are asymptomatic but who would benefit from such treatment (Raman et al., 2010). Up to $10-30 \%$ of Western populations are affected by GORD (Spechler, 1992; Frank et al., 2000; Holtmann, 2001), there is a higher prevalence amongst lung disease patients and there is evidence suggesting that the prevalence of GORD is increasing (Friedenberg et al., 2010). Now more than ever, further research into standard and novel methods of diagnosis is needed.

\section{CONCLUSION}

Gastroesophageal reflux disease is a prevalent disorder in Western countries and is increasing in prevalence. GORD can cause significant morbidity and have an impact on quality of life, particularly in association with lung disease. Whilst debate continues as to whether lung disease exacerbates GORD or GORD exacerbates lung disease, accurate diagnosis, and subsequent treatment of this disease should be able to improve outcome. Diagnosis of GORD is an evolving field but research is hampered by blurred definitions of what constitutes GORD. Measurement of exhaled breath and $\mathrm{EBC}$ in reflux patients may represent the intermediate step between diagnostic accuracy and non-invasive sampling. Whilst research has demonstrated potential in these methods, further research needs to be undertaken in large populations, preferably comparing electronic nose, and EBC to other methods of diagnosis. 


\section{REFERENCES}

Aanen, M. C., Bredenoord, A. J., Samsom, M., and Smout, A. J. P. M. (2008). Reliability of oesophageal $\mathrm{pH}$ recording for the detection of gastro-oesophageal reflux. Scand. J. Gastroenterol. 43, 1442-1447.

Abd El-Fattah, A. M., Abdul Maksoud, G. A., Ramadan, A. S., Abdalla, A. F., and Abdel Aziz, M. M. (2007). Pepsin assay: a marker for reflux in pediatric glue ear. Otolaryngol. Head Neck Surg. 136, 464-470.

Amarasiri, L., Pathmeswaran, A., de Silva, H. J., and Ranasinha, C. (2010). Prevalence of gastro-oesophageal reflux disease symptoms and refluxassociated respiratory symptoms in asthma. BMC Pulm. Med. 10, 49. doi: 10.1186/1471-2466-10-49

Amine, H., Amit, A., and Donald, O. C. (2007). Combined multichannel intraluminal impedance and $\mathrm{pH}$ esophageal testing compared to $\mathrm{pH}$ alone for diagnosing both acid and weakly acidic gastroesophageal reflux. Clin. Gastroenterol. Hepatol. 5, 172-177.

Antus, B., Barta, I., Kullmann, T., Lazar, Z., Valyon, M., Horvath, I., and Csiszer, E. (2010). Assessment of exhaled breath condensate $\mathrm{pH}$ in exacerbations of asthma and chronic obstructive pulmonary disease: a longitudinal study. Am. J. Respir. Crit. Care Med. 182, 1492-1497.

Baron, T. H., and Richter, J. E. (1992). Gastroesophageal reflux disease in pregnancy. Gastroenterol. Clin. North Am. 21, 777-791.

Bate, C. M., Riley, S. A., Chapman, R. W., Durnin, A. T., and Taylor, M. D. (1999). Evaluation of omeprazole as a cost-effective diagnostic test for gastro-oesophageal reflux disease. Aliment. Pharmacol. Ther. 13, 59-66.

Beaumont, H., Bennink, R. J., de Jong, J., and Boeckxstaens, G. E. (2010). The position of the acid pocket as a major risk factor for acidic reflux in healthy subjects and patients with GORD. Gut 59, 441-451.

Brunetti, L., Tesse, R., Francavilla, R., Miniello, V. L., Strippoli, A., De Sario, V., Fiore, F., and Armenio, L. (2004). The $\mathrm{pH}$ of exhaled breath condensate (EBC): a non invasive tool for evaluation of asthma in childhood. J. Allergy Clin. Immunol. 113, S266.

Canning, B. J., and Mazzone, S. B. (2003). Reflex mechanisms in gastroesophageal reflux disease and asthma. Am. J. Med. 115, 45-48.

Casanova, C., Baudet, J. S., del Valle Velasco, M., Martin, J. M., AguirreJaime, A., Pablo de Torres, J., and Celli, B. R. (2004). Increased gastro-oesophageal reflux disease in patients with severe COPD. Eur. Respir. J. 23, 841-845.

Chen, Z., Warwick, G., Yates, D. H., and Thomas, P. S. (2009). An electronic nose in the discrimination of breath from smokers and non-smokers: a model for toxin exposure. J. Breath Res. 3, 1-5.

Cho, Y. K., Choi, M. G., Lim, C. H., Nam, K. W., Chang, J. H., Park, J. M., Lee, I. S., Kim, S. W., Choi, K. Y., and Chung, I. S. (2010). Diagnostic value of the PPI test for detection of GERD in Korean patients and factors associated with PPI responsiveness. Scand. J. Gastroenterol. 45, 533-539.

Dallinga, J. W., Robroeks, C. M. H. H. T., Van Berkel, J. J. B. N., Moonen, E. J. C., Godschalk, R. W. L., Jöbsis, Q., Dompeling, E., Wouters, E. F., and van Schooten, F. J. (2010). Volatile organic compounds in exhaled breath as a diagnostic tool for asthma in children. Clin. Exp. Allergy 40, 68-76.

D’Amico, A., Pennazza, G., Santonico, M., Martinelli, E., Roscioni, C., Galluccio, G., Paolesse, R., and Di Natale, C. (2010). An investigation on electronic nose diagnosis of lung cancer. Lung Cancer 68, 170-176.

Dean, B. B., Aguilar, D., Johnson, L. F., Fass, R., Orr, W. C., McGuigan, J. E., Calimlim, B., Yan, N., Morgenstern, D., and Dubois, R. W. (2010). The relationship between the prevalence of nighttime gastroesophageal reflux disease and disease severity. Dig. Dis. Sci. 55, 952-959.

Delaney, B. C. (2004). Review article: prevalence and epidemiology of gastro-oesophageal reflux disease. Aliment. Pharmacol. Ther. 20(Suppl. 8), 2-4.

Dent, J., El-Serag, H. B., Wallander, M.-A., and Johansson, S. (2005). Epidemiology of gastro-oesophageal reflux disease: a systematic review. Gut 54, 710-717.

Dent, J., Vakil, N., Jones, R., Bytzer, P., Schoning, U., Halling, K., Junghard, O., and Lind, T. (2010). Accuracy of the diagnosis of GORD by questionnaire, physicians and a trial of proton pump inhibitor treatment: the diamond Study. Gut 59, 714-721.

Eryuksel, E., Dogan, M., Olgun, S., Kocak, I., and Celikel, T. (2009). Incidence and treatment results of laryngopharyngeal reflux in chronic obstructive pulmonary disease. Eu. Arch. Otorhinolaryngol. 266, 1267-1271.

Farrell, S., McMaster, C., Gibson, D., Shields, M. D., and McCallion, W. A. (2006). Pepsin in bronchoalveolar lavage fluid: a specific and sensitive method of diagnosing gastro-oesophageal refluxrelated pulmonary aspiration. $J$. Pediatr. Surg. 41, 289-293.

Fass, R., Fennerty, M. B., Ofman, J. J., Gralnek, I. M., Johnson, C., Camargo, E., and Sampliner, R. E. (1998). The clinical and economic value of a short course of omeprazole in patients with noncardiac chest pain. Gastroenterology 115 , 42-49.

Fens, N., Zwinderman, A. H., van der Schee, M. P., de Nijs, S. B. Dijkers, E., Roldaan, A. C., Cheung, D., Bel, E. H., and Sterk, P. J. (2009). Exhaled breath profiling enables discrimination of chronic obstructive pulmonary disease and asthma. Am. J. Respir. Crit. Care Med. 180, 1076-1082.

Fisichella, P., and Patti, M. (2009). Gastroesophageal reflux disease and morbid obesity: is there a relation? World J. Surg. 33, 2034-2038.

Frank, L., Kleinman, L., Ganoczy, D., McQuaid, K., Sloan, S., Eggleston, A., Tougas, G., and Farup, C. (2000). Upper gastrointestinal symptoms in North America. Dig. Dis. Sci. 45, 809-818.

Friedenberg, F., Hanlon, A., Vanar, V., Nehemia, D., Mekapati, J., Nelson, D., and Richter, J. E. (2010). Trends in gastroesophageal reflux disease as measured by the National Ambulatory Medical Care Survey. Dig. Dis. Sci. 55, 1911-1917.

Gibson, P. G., Henry, R. L., and Coughlan, J. L. (2000). Gastro-oesophageal reflux treatment for asthma in adults and children. Cochrane Database Syst. Rev. 2, CD001496.

Holtmann, G. (2001). Reflux disease: the disorder of the third millennium. Eur. J. Gastroenterol. Hepatol. 13(Suppl. 1), S5-S11.

Hunt, J. F., Fang, K., Malik, R., Snyder, A., Malhotra, N., Platts-Mills, T. A., and Gaston, B. (2000). Endogenous airway acidification: implications for asthma pathophysiology. Am. J. Respir. Crit. Care Med. 161, 694-699.

Hyspler, R., Crhová, S., Gasparic, J. Zadák, Z., Cízková, M., and Balasová, V. (2000). Determination of isoprene in human expired breath using solid-phase microextraction and gas chromatography-mass spectrometry. J. Chromatogr. B Biomed. Sci. Appl. 739, 183-190.

Isolauri, J., and Laippala, P. (1995). Prevalence of symptoms suggestive of gastroesophageal reflux disease in an adult population. Ann. Med. 27, 67-70.

Kempainen, R. R., Savik, K., Whelan, T. P., Dunitz, J. M., Herrington,
C. S., and Billings, J. L. (2007) High prevalence of proximal and distal gastroesophageal reflux disease in advanced COPD ${ }^{\star}$. Chest 131 , 1666-1671.

Kiljander, T. O., and Laitinen, J. O. (2004). The prevalence of gastroesophageal reflux disease in adult asthmatics*. Chest 126, 1490-1494.

Krishnan, A., Chow, S., Thomas, P. S., Malouf, M. A., Glanville, A. R., and Yates, D. H. (2007). Exhaled breath condensate pepsin: a new noninvasive marker of GERD after lung transplantation. J. Heart Lung Transplant. 26, 221. [Meeting Abstract].

Krishnan, U., Mitchell, J. D., Messina, I., Day, A. S., and Bohane, T. D. (2002). Assay of tracheal pepsin as a marker of reflux aspiration. J. Pediatr. Gastroenterol. Nutr. 35, 303-308.

Kusano, M., Shimoyama, Y., Sugimoto, S., Kawamura, O., Maeda, M., Minashi, K., Kuribayashi, S., Higuchi, T., Zai, H., Ino, K., Horikoshi, T., Sugiyama, T., Toki, M., Ohwada, T., and Mori, M. (2004). Development and evaluation of FSSG: frequency scale for the symptoms of GERD. J. Gastroenterol. 39, 888-891.

Leggett, J. J., Johnston, B. T., Mills, M., Gamble, J., and Heaney, L. G. (2005). Prevalence of gastroesophageal reflux in difficult asthma*. Chest 127, 1227-1231.

Machado, R. F., Laskowski, D., Deffenderfer, O., Burch, T., Zheng, S., Mazzone, P. J., Mekhail, T., Jennings, C., Stoller, J. K., Pyle, J., Duncan, J., Dweik, R. A., and Erzurum, S. C. (2005). Detection of lung cancer by sensor array analyses of exhaled breath. Am. J. Respir. Crit. Care Med. 171, 1286-1291.

Maher, M. M., and Darwish, A. A. (2010). Study of respiratory disorders in endoscopically negative and positive gastroesophageal reflux disease. Saudi J. Gastroenterol. 16, 84-89.

McNally, P., Ervine, E., Shields, M. D., Dimitrov, B. D., El Nazir, B., Taggart, C. C., Greene, C. M., McElvaney, N. G., and Greally, P. (2011). High concentrations of pepsin in bronchoalveolar lavage fluid from children with cystic fibrosis are associated with high interleukin- 8 concentrations. Thorax 66, 140-143.

Montuschi, P., Santonico, M., Mondino, C., Pennazza, G., Mantini, G., Martinelli, E., Capuano, R., Ciabattoni, G., Paolesse, R., Di Natale, C., Barnes, P. J., and D'Amico, A. (2010). Diagnostic performance of an electronic nose, fractional exhaled nitric oxide, and lung function testing in asthma. Chest 137, 790-796. 
Pandak, W. M., Arezo, S., Everett, S., Jesse, R., DeCosta, G., Crofts, T., Gennings, C., Siuta, M., and Zfass, A. (2002). Short course of omeprazole: a better first diagnostic approach to noncardiac chest pain than endoscopy, manometry, or 24hour esophageal $\mathrm{pH}$ monitoring. J. Clin. Gastroenterol. 35, 307-314.

Pavlou, A. K., Magan, N., McNulty, C., Jones, J. M., Sharp, D., Brown, J., and Turner, A. P. (2002). Use of an electronic nose system for diagnoses of urinary tract infections. Biosens. Bioelectron. 17, 893-899.

Pearson, J. P., Parikh, S., Orlando, R. C., Johnston, N., Allen, J., Tinling, S. P., Johnston, N., Belafsky, P., Arevalo, L. F., Sharma, N., Castell, D. O., Fox, M., Harding, S. M., Morice, A. H., Watson, M. G., Shields, M. D., Bateman, N., McCallion, W. A., van Wijk, M. P., Wenzl, T. G., Karkos, P. D., and Belafsky, P. C. (2011). Review article: reflux and its consequences - the laryngeal, pulmonary and oesophageal manifestations. Conference held in conjunction with the 9th International Symposium on Human Pepsin (ISHP), Kingston-upon-Hull. [Aliment. Pharmacol. Ther. 33(Suppl. 1), 1-71].

Ping, W., Yi, T., Haibao, X., and Farong, S. (1997). A novel method for diabetes diagnosis based on electronic nose. Biosens. Bioelectron. 12, 1031-1036.
Raman, A., Sternbach, J., Babajide, A., Sheth, K., and Schwaitzberg, S. (2010). When does testing for GERD become cost effective in an integrated health network? Surg. Endosc. 24, 1245-1249.

Rascon-Aguilar, I. E., Pamer, M., Wludyka, P., Cury, J., Coultas, D., Lambiase, L. R., Nahman, N. S., and Vega, K. J. (2006). Role of gastroesophageal reflux symptoms in exacerbations of COPD ${ }^{\star}$. Chest 130 , 1096-1101.

Reid, B. J., Weinstein, W. M., Lewin, K. J., Haggitt, R. C., VanDeventer, G., DenBesten, L., and Rubin, C. E. (1988). Endoscopic biopsy can detect high-grade dysplasia or early adenocarcinoma in Barrett's esophagus without grossly recognizable neoplastic lesions. Gastroenterology 94, 81-90.

Rubin, G., Uebel, P., Brimo-Hayek, A., Hey, K. H., Doerfler, H., and Heading, R. C. (2008). Validation of a brief symptom questionnaire (ReQuest in Practice) for patients with gastro-oesophageal reflux disease. Aliment. Pharmacol. Ther. 27, 846-851.

Sise, A., and Friedenberg, F. K. (2008). A comprehensive review of gastroesophageal reflux disease and obesity. Obesity Rev. 9, 194-203.

Spechler, S. J. (1992). Epidemiology and natural history of gastrooesophageal reflux disease. Digestion 51(Suppl. 1), 24-29.
Starosta, V., Kitz, R., Hartl, D., Marcos, V., Reinhardt, D., and Griese, M. (2007). Bronchoalveolar pepsin, bile acids, oxidation, and inflammation in children with gastroesophageal reflux disease* ${ }^{\star}$ Chest 132 , 1557-1564.

Strugala, V., Dettmar, P. W., and Morice, A. H. (2009). S1895 Detection of pepsin in sputum and exhaled breath condensate: could it be a useful marker for reflux-related respiratory disease? Gastroenterology, 136(5 Suppl. 1), A-287.

Terada, K., Muro, S., Sato, S., Ohara, T. Haruna, A., Marumo, S., Kinose, D. Ogawa, E., Hoshino, Y., Niimi, A. Terada, T., and Mishima, M. (2008) Impact of gastro-oesophageal reflux disease symptoms on COPD exacerbation. Thorax 63 , 951-955.

Thaler, E. R., Bruney, F. C., Kennedy, D. W., and Hanson, C. W. (2000). Use of an electronic nose to distinguish cerebrospinal fluid from serum. Arch. Otolaryngol. Head Neck Surg. 126, 71-74.

Tran, V. H., Chan, H. P., Thurston, M. Jackson, P., Yates, D., Bell, G., and Thomas, P. S. (2010). Breath analysis of lung cancer patients using an electronic nose. IEEE Sens. J. 10, 1514-1518.

Vakil, N., van Zanten, S. V., Kahrilas, P., Dent, J., and Jones, R. (2006). The Montreal definition and classification of gastroesophageal reflux disease: a global evidence-based consensus. Am. J. Gastroenterol. 101, 1900-1920.

Ward, C., Forrest, I. A., Brownlee, I. A., Johnson, G. E., Murphy, D. M., Pearson, J. P., Dark, J. H., and Corris, P. A. (2005). Pepsin like activity in bronchoalveolar lavage fluid is suggestive of gastric aspiration in lung allografts. Thorax 60, 872-874.

Conflict of Interest Statement: The authors declare that the research was conducted in the absence of any commercial or financial relationships that could be construed as a potential conflict of interest.

Received: 24 March 2011; paper pending published: 17 May 2011; accepted: 07 July 2011; published online: 22 July 2011.

Citation: Timms CJ, Yates DH and Thomas PS (2011) Diagnosing GORD in respiratory medicine. Front. Pharmacol. 2:40. doi: 10.3389/fphar.2011.00040 This article was submitted to Frontiers in Respiratory Pharmacology, a specialty of Frontiers in Pharmacology.

Copyright (c) 2011 Timms, Yates and Thomas. This is an open-access article subject to a non-exclusive license between the authors and Frontiers Media $S A$, which permits use, distribution and reproduction in other forums, provided the original authors and source are credited and other Frontiers conditions are complied with. 